\title{
114. Cunninghamia nodensis sp. nov., from the Palaeogene Noda Group, Northeast Japan*)
}

\author{
By Tatsuaki Kimura and Junji HorIUCHI \\ Tokyo Gakugei University
}

(Communicated by Teiichi Kobayashi, M. J. A., Dec. 12, 1978)

This paper is the second one by us on the fossil plants from the Noda Group, Iwate Prefecture, Northeast Japan, and deals with the description of Cunninghamia nodensis newly recognized from the Minato Formation.

\section{Coniferales Taxodiaceae}

\section{Genus Cunninghamia R. Brown, 1826}

Extant species are only two, Cunninghamia konishii Hayata restricted in distribution to Formosa, and $C$. lanceolata HoOk $(=C$. sinensis R. Brown) to South China, Formosa and Viet-Nam. Rather sporadical fossil records of this genus in Japan have been known as follows.

Cunninghamia eocenica Matsuo, 1967; Eocene Takashima Group (detached cones and cone-scales).

C. izumiensis Matsuo, 1966; Upper Cretaceous Izumi Group (leafy branches and a detached cone $=C$. sp. Matsuo, 1954).

C. Konishii Hayata; Miki, 1941, Pliocene to Pleistocene plant beds in Southwest Japan (leafy branches and detached cones) ; Miki, 1950, Pliocene to Pleistocene plant beds in Southwest Japan (leafy branches, cones and conescales).

C. protokonishii Tanai and Onoé, 1960; Tanai and Onoé, 1961, Miocene Onbara Formation, Okayama Prefecture (a leafy branch); Murai, 1962, Middle-Upper Miocene Sakamotozawa and Masuzawa Formations, Iwate Prefecture (leafy branches) ; Huzioka, 1963, Middle Miocene Utto Formation, Akita Prefecture (a leafy branch); Ishida, 1970, Middle Miocene Yanagida Formation, Ishikawa Prefecture (a leafy branch) ; Huzioka and Uemura, 1973, Upper Miocene Miyata Formation, Akita Prefecture (leafy branches).

C. sp. Matsuo, 1970, Upper Cretaceous Omichidani Formation, Ishikawa Prefecture (leafy branches).

Cunninghamiostrobus yubariensis Stopes and Fujii, 1910; Senonian (s. s.) Upper Yezo Group, Hokkaido (a detached cone).

No cuticular study on the fossil Cunninghamia leaves in Japan had so far been carried out until the present work. The cuticles here described were prepared by the maceration with $\mathrm{HNO}_{3}+\mathrm{KClO}_{3}$ followed by diluted $\mathrm{NaOH}$.

*) Studies on Japanese fossil conifers-2. Supported by the Scientific Research Fund of the Ministry of Education, Japan; no. 354290 (1978). 
Cunninghamia nodensis Kimura and Horiuchi sp. nov.

Figs. 1-5

Type specimen: Holotype; MI-08032 (slide, MI-08032a). All specimens and slides here described are deposited in Department of Astronomy and Earth Sciences, Tokyo Gakugei University. Horizon: Minato Formation, Noda Group (The exact horizon will be shown in our later paper by the columnar section).

Diagnosis: Ultimate branches stout, 1-4 $\mathrm{mm}$ across at the internode, reaching $7 \mathrm{~mm}$ across at or near the node, consisting of 1-3 in number at a node. Leaves spirally arranged on every branch at an angle of 50-90 degrees. Leaves lanceolate in form, with acutely pointed apex, decurrent base without petiole and microscopically loosely undulated margins. Leaves dimorphic in size; usual ones 0.8 $1.7 \mathrm{~cm}$ long and $0.2-0.3 \mathrm{~cm}$ wide; small ones $0.3 \mathrm{~cm}$ long and $1.2 \mathrm{~mm}$ wide, restricted on the basal part of each ultimate branch.

Cuticle hypostomatic. Upper cuticle consisting only of normal cells. No special cells along the median part and leaf margins. Upper normal cells rectangular in form, $48-160 \mu$ long and $15-20 \mu$ wide; end walls square or oblique, straight or slightly undulated; anticlinal walls mostly straight but sometimes slightly undulated, and with knob-like thickenings inward, 6-9 $\mu$ in interval on each side, each knob-like thickening sending off a spine-like projection from its tip inward, nearly perpendicularly to the wall. Several circular granules,

Figs. 1-5. Cunninghamia nodensis sp. nov. 1: Leafy branches (holotype, MI-08032). Many leafy branches were obtained. Margins of leaves are macroscopically entire, but microscopically loosely undulated. 2: Upper cuticle consisting only of normal cells, inside of which knob-like thickenings with spine-like projections are distinct. Normal cells located at or near the leaf-margins and the leaf-apex are generally longer and narrower than those located along the median part of a leaf (slide no. MI08032e). 3: Lower cuticle of the right half of a leaf, consisting of a stomate cells zone, a median normal cells zone (left) and a marginal normal cells zone (right). The arrow points the border between the lower and the upper cuticles, where deformed normal cells are not recognized (slide no. MI-08032a). In extant species, marginal normal cells are usually deformed to form the serration. 4: A part of stomate cells zone enlarged from Fig. 3 to show four distinct stomata in which subsidiary and encircling cells are similar in form and size, and the inner thickenings of subsidiary cells are clearly seen. 5: Lower normal cells on which many circular granules are scattered over the cell-surface, but not over its margins. Such granules are more crowded in marginal normal cells (slide no. MI-08032b).

Figs. 6-7 are Cunninghamia lanceolata (extant) and C. konishii (extant), showing a part of stomate cells zone for comparison. According to our observation, both species are clearly amphistomatic, especially so in $C$. konishii (from the Asakawa Arboretum, Forestry and Forest Productus Research Institute, Tokyo). 
about $3 \mu$ in diameter scattered on the surface of each normal cell.

Lower cuticle consisting of normal cells and stomate cells. Normal cells similar in form and nature to those of upper cuticle, 35-133 $\mu$ long and 12-38 $\mu$ wide, forming normal cells zone along a median part and margins. Circular granules, $5-10 \mu$ in diameter scattered on the surface of each normal cell, 0-17, mostly 9 in number. Stomate cells consisting of guard cells, subsidiary cells and encircling cells, forming two symmetrical stomate zones on a leaf; a single stomate zone consisting of 6-7 stomate rows, but fewer near leaf apex. Guard cells rectangular or elongate-pentagonal in form, 22-40 $\mu$ long and $6.25-10 \mu$ wide; apertures mostly parallel to the elongation of leaf but sometimes nearly perpendicular to it. Subsidiary cells polygonal, mostly hexagonal in form, with straight walls, 35-45 $\mu$ in diameter, surrounding a guard cell pair; inner cell walls thickened. Encircling
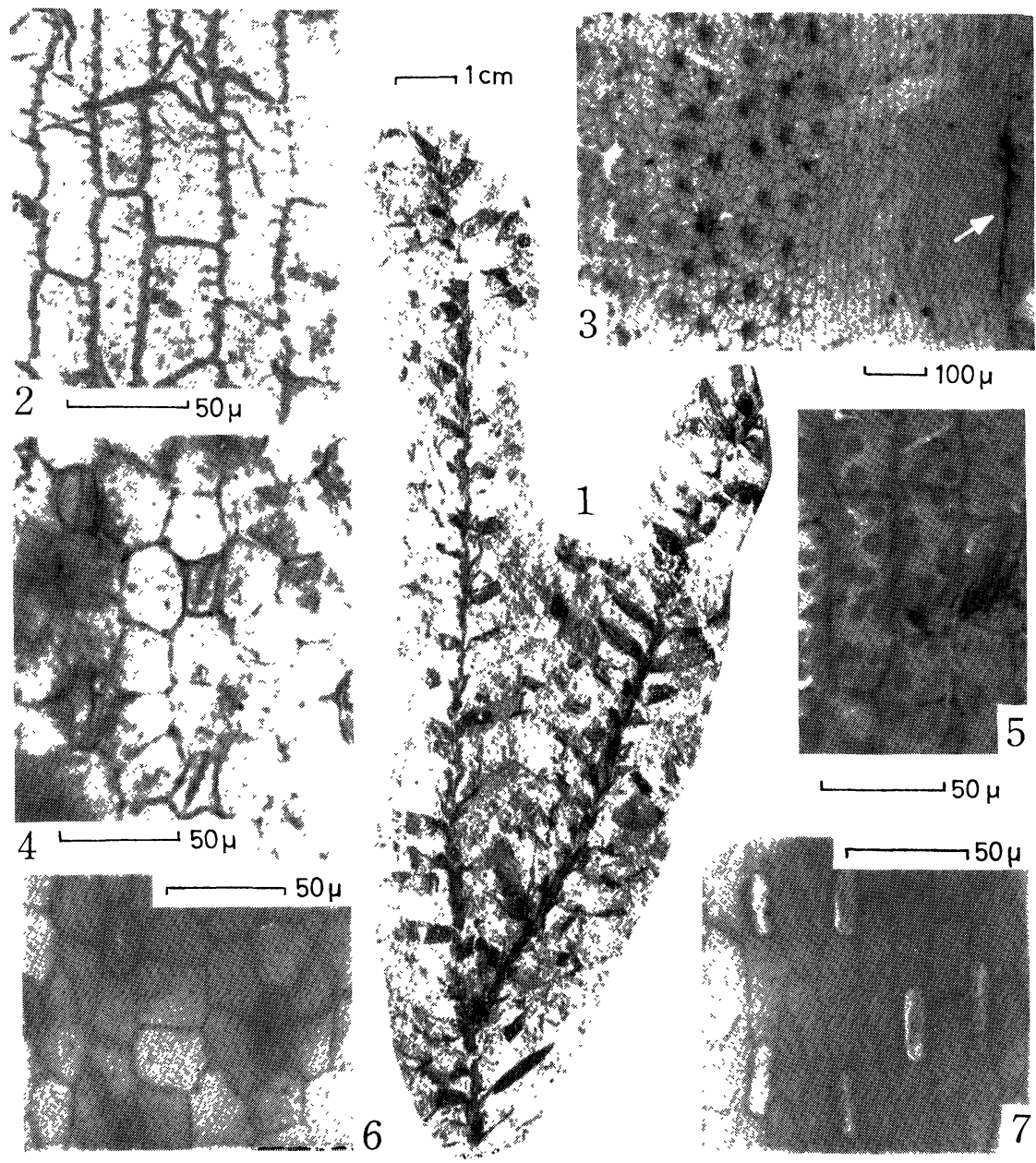
cells similar in size and form to subsidiary cells. Stomata 6-7 per $200 \mu^{2}$ of stomate zone. (Fructification not known.)

Comparison and discussion: It would be difficult to establish the exact attribution of the present leafy branches depending only on their external form. Indeed, the present leafy branches look like those of Torreya. However, it is sure that the present leafy branches belong to the genus Cunninghamia and are distinguishable from those of other conifers hitherto known, because their subsidiary and encircling cells are quite similar in form and disposition to those of extant Cunninghamia species, and moreover the spinose structure on the normal celi walls is a characteristic feature of the genus.

The present Cunninghamia nodensis is characterized by its lanceolate leaf-form without marginal serration and hypostomatic cuticle.

We could not make the full comparison between Cunninghamia nodensis and other fossil Cunninghamia records in Japan, because the latter specimens were represented by the impression of leaves and solely by cones or cone-scales. Cunninghamia izumiensis, though without serrate margins in its leaves, differs distinctly from $C$. nodensis in its external leaf-form.

Cunninghamia nodensis differs from both the extant species in having shorter leaves without marginal serrations and no stomata on the upper side. Moreover, Cunninghamia konishii has narrower subsidiary and encircling cells (Fig. 7).

So far as we know, the fossil Cunninghamia leaves with preserved cuticle are as follows; Cunninghamia angustifolia Sveshnikova, 1967 (Late Cretaceous, Lena Basin), C. borzeana Givulescu, 1968, 1975 (Neogene, Rumania), C. europaea Szafer, 1961 (Miocene, Silesia), C. heeri Sveshnikova and Budanzev, 1963 (Oligocene, Moscow) and $C$. sp. Givulescu, 1972 (Neogene, Rumania).

Cunninghamia nodensis differs distinctly from $C$. angustifolia in its external leaf-form. Cunninghamia nodensis resembles C. borzeana in having no marginal serrations but differs distinctly in its external leaf-form, too. Cunninghamia europaea differs distinctly from $C$. nodensis in having strongly dentate leaf-margins. Cunninghamia heeri seems the most similar in cuticular character to $C$. nodensis, but differs in being amphistomatic and in different forms of subsidiary and encircling cells, and moreover in having marginal serrations.

So far as the fossil Cunninghamia is concerned, the circular granules on the normal cells have not been described, but their existence in other fossil Cunninghamia species is clear by our observation of their plates.

Alvin and Boulter (1974) mentioned that these granules (regarded by them as papillae) were a remarkable feature of Cun- 
ninghamia lanceolata and they were $3 \mu$ in diameter. They are 5-10 $\mu$ in diameter in $C$. nodensis, $5 \mu$ in $C$. heeri and 6-7 $\mu$ in C. borzeana, according to our measurement.

Acknowledgements. We first express our sincere gratitude to Professor Emeritus Thomas M. Harris, F.R.S. of the University of Reading for his very helpful suggestions and kindest reading over the present manuscript. We are indebted to Professor Emeritus Teiichi Kobayashi, M. J. A., of the University of Tokyo for giving us the facilities to publish this paper. We also thank Mr. Yoshio Kobayashi of the Asakawa Arboretum, Forestry and Forest Productus Research Institute, for giving us the extant specimens.

\section{References}

Alvin, K. L., and Boulter, M. C. (1974): A controlled method of comparative study for Taxodiaceous leaf cuticles. Bot. J., Linn. Soc., 69(4), 211-286, pls. 1-5.

Givulescu, R. (1968): Die Gattung Cunninghamia R. Br. im unteren Pannon Rumäniens. N. Jb. Geol. Paläont. Abh., 130(2), 129-132, pls. 14-15.

- (1972): Sur quelques restes de Cunninghamia du Néogène de Roumanie. Bull. Mens. Soc. Linn. Lyon, 5, 83-85.

(1975) : Fossile Pflanzen aus dem Pannon von Delureni (Rumänien). Palaeontographica, Abt. B, 153, 150-182, pls. 1-13.

Huzioka, K. (1963) : The Utto flora of Northern Honshu. Tertiary Floras of Japan. Miocene Floras. Geol. Surv. Japan, pp. 153-216, pls. 28-40.

Huzioka, K., and Uemura, K. (1973): The late Miocene Miyata flora of Akita Prefecture, Northeast Honshu, Japan. Bull. Natn. Sci. Mus., 16(4), 661-738, pls. 1-18.

Ishida, S. (1970): The Noroshi flora of Noto Peninsula, Central Japan. Mem. Fac. Sci., Kyoto Univ., ser. Geol. Min., $37(1), 1-112$, pls. 1-22.

Matsuo, H. (1954): On the occurrence of the Genus Cunninghamia from the Izumi Sandstone Group (Upper Cretaceous). J. Geol. Soc. Japan, 60(707), 362, 1 text-fig. (in Japanese).

- (1963): The Notonakajima flora of Noto Peninsula. Tertiary Floras of Japan. Miocene Floras. Geol. Surv. Japan, pp. 219-243, pls. 41-56.

- (1966) : Plant fossils of the Izumi Group (Upper Cretaceous) in the Izumi Mountain Range, Kinki District, Japan. Ann. Sci., Coll. Lib. Arts, Kanazawa Univ., 3, 67-74, pl. 1.

- (1967) : Palaeogene floras of Northwestern Kyushu. Part 1: The Takashima flora. Ibid., 4, 15-90, incl. pls. 1-11.

- (1970): On the Omichidani flora (Upper Cretaceous), Inner Side of Central Japan. Trans. Proc. Palaeont. Soc. Japan, N. S., no. 80, 371-389, pls. $42-43$.

Miki, S. (1941): On the change of flora in Eastern Asia since Tertiary Period (1). The clay or lignite beds flora in Japan, with special reference to the Pinus trifolia beds in Central Hondo. Japan. J. Bot., 11, 237-303, pls. 4-7.

- (1950): Taxodiaceae in Japan, with special reference to its remains. J. Inst. Polytech., Osaka City Univ., ser. D, 1, 1-15.

Murai, S. (1962): Geology and palaeontology of the Shizukuishi Basin, Iwate Prefecture, Japan (Part II-1). Rep. Tech., Iwate Univ., 15 (2), 1-34, pls. 1-9.

Stopes, M. C., and Fujii, K. (1910): Studies on the structure and affinities of Cretaceous rocks. Phil. Trans. Roy. Soc. London, ser. B, 201, 1-90, pls. 1-9. 
Sveshnikova, I. N. (1963) : Atlas and key for the identification of the living and fossil Sciadopityaceae and Taxodiaceae based on the structure of the leaf epiderm. Komarov Bot. Inst., Acad. Sci. USSR, ser. 8, 4, 207-229, pls. 1-17 (in Russian).

(1967) : Late Cretaceous Coniferae of the U.S.S.R.1. Fossil Coniferae of the Viliuyian Depression. Ibid., 6, 179-203, pls. 1-12 (in Russian).

Szafer, W. (1961): Miocene flora from Stare Gliwice in Upper Silesia. Inst. Geol. Prace, Warszawa, 33, 1-205, pls. 1-26 (in Polish with English description and notes).

Tanai, T., and Onoé, T. (1961): A Mio-Pliocene flora from the Ningyotoge area on the border between Tottori and Okayama Prefectures, Japan. Rep. Geol. Surv. Japan, no. 187, 1-63, pls. 1-18. 